\title{
KEDUDUKAN ANAK ANGKAT DALAM PEWARISAN MENURUT HUKUM ADAT BALI (STUDI KASUS DESA ADAT GUNAKSA)
}

\author{
I Nengah Sunaradana, I Wayan Rideng, Diah Gayatri Sudibya \\ Fakultas Hukum, Universitas Warmadewa, Denpasar-Bali, Indonesia \\ sunamdana55@gmail.com, wyrideng@gmail.com, diahgayatrisudibya@gmail.com
}

\begin{abstract}
Abstrak
Kedudukan anak angkat dalam pewarisan berdasarkan hukum adat Bali memang telah ditetapkan guna memberikan hak bagi anak angkat. Tujuan penelitian ini yaitu untuk mengkaji tata cara adat pengangkatan anak menurut Hukum Adat Bali serta kedudukan anak angkat terkait harta warisan orang tuanya (biologis dan angkat). Penelitian ini menggunakan menggunaka metode hukum empiris dengan pendekatan yuridis dan sosiologis. Sumber bahan hukum yang digunakan adalah bahan hukum primer dan sekunder. Bahan hukum dalam studi ini dikumpulkan dengan dua teknik pengumpulan data, yaitu teknik wawancara dan dokumentasi. Kemudian, pemilihan sampel dalam studi ini dilakukan dengan Purposive Sampling Technique, kemudian dianalisa secara sistematis. Hasil penelitian menunjukkan bahwa kedudukan seorang anak angkat sama dengan anak kandung -berperan sebagai pewaris dan penerus yang sah-jika berasal dari keluarga besar orang tua angkat. Pewarisan harta peninggalan orang tua angkat akan diserahkan sepenuhnya kepada anak angkat laki-laki termasuk pusaka keluarga orang tua angkatnya. Sedangkan, kedudukan anak angkat hanya sebatas pewaris harta guna kaya saja apabila berasal dari luar keluarga besar orang tua angkatnya-kepemilikan pusaka kepada pemilik sah. Dalam kondisi ini, apabila orang tua angkat meninggal dunia, maka hubungan kekeluargaan antara anak angkat dan orang tua angkatnya terputus.
\end{abstract}

Kata Kunci: Anak Angkat, Harta Warisan, Hukum Adat

\begin{abstract}
The position of adopted children in inheritance based on Balinese customary law has indeed been determined to provide rights for adopted children. This research aimed to examine the customary procedures for adopting children according to Balinese Customary Law and the position of adopted children related to the inheritance of their parents (biological and adoptive). This research uses empirical legal methods with juridical and sociological approaches. The sources of legal materials used are primary and secondary. The legal materials in this research were collected using two data collection techniques, namely interview and documentation techniques. Then, the sample selection in this research was carried out by using purposive sampling technique, then it was analyzed systematically. The results of the research indicates that the position of an adopted child is the same as that of a biological child - acting as the legal heir and successor - if he comes from a large family of adoptive parents. The inheritance of the adoptive parents' inheritance will be fully handed over to the adopted son, including the family heirloom of his adoptive parents. Meanwhile, the position of adopted children is only limited to the inheritor of wealthy assets if they come from outside the extended family of the adopted parent inheritance to the legal owner. In this condition, if the adoptive parents die, then the family relationship between the adopted child and the adoptive parents is severed.
\end{abstract}

Keywords: Adopted Children, Inheritance, Customary Law

\section{PENDAhuluan}

Di Indonesia, fenomena pengadopsian anak sudah sangat lazim meskipun pada masing-masing daerah adat, terdapat berbagai macam tata cara dan sistem yang berbeda. Dalam beberapa kasus, anak angkat memutuskan sama sekali hubungannya dengan orang tua kandung, dan di lain tempat ada pula yang tetap mendapatkan hak unruk menyambung hubungan dengan orang tua biologisnya. Dalam pendapatnya, wajar jika seseorang memiliki dorongan emosional terhadap kepemilikan anak, dan hal ini terjadi pada semua orang sebagai seorang manusia karena anak akan menjadi penerus yang mewarisi segala hal tentang orangtuanya (Zaini, 2002).

Di lain kesempatan, Soepomo berpendapat bahwa tindakan melepaskan hubungan antara anak angkat dan orang tua kandung adalah hal yang umum dalam fenomena pengangkatan anak karena 
statusnya yang biasanya berada pada posisi seperti layaknya anak kandung dalam keluarga orang tua angkatnya (Soepomo, 2000). Sedangkan, dalam adat bali, mengangkat seorang anak kedalam keluarga dengan rujuan menjadikannya pewaris dan penerus sama halnya dengan memposisikan anak tersebut menjadi anak kandung orang tua yang mengangkatnya sebagai anak dalam keluarga mereka.

Penting untuk diketahui bahwa sistem kekeluargaan patrilineal adalah yang dianut dalam kehidupan masyarakat hukurn adat Bali. Hal ini berarti segala macam hal dan kepurusan terkait kekeluargaan dilihat dari posisi garis keturunan sang ayah dalam sebuah keluarga. Adanya kondisi ini menjadikan keberadaan dan peranan anak laki-laki dalam sebuah keluarga di Bali menjadi sangat krusial. Kewajiban dan tanggung jawab, seperti hal ihwal mengenai pemujaan leluhur dan pemeliharaan serta pewarisan peninggalan orang tua di predikatkan kepada seorang anak laki-laki.

Pada kasus yang terjadi di salah satu desa di Bali (Gunaksa), anak laki-laki yang akan diangkat sebagai seorang anak dalam keluarga dianjurkan adalah mereka yang berasal dari lingkungan keluarga calon orang tua angkat-masih memiliki tali persaudaraan. Dalam hukum adatnya, proses pengangkatan seorang anak di Bali akan dilaksanakan melalui upacara adat yang dikenal dengan nama pemerasan dengan beberapa fase, terrnasuk didalamya proses puputan oleh rohaniawan (Ida pedanda) yang, oleh kelian adat, disiarkan saat sangkepan banjar dengan kedua belah pihak keluarga sebagai saksi, didampingi oleh Kelian Pemaksan, Pemangku Paibon, Kelian Paibon, Kepala Desa, Bendesa Adat, dan Kelian Banjar Adat. Kemudian, sebagai bukti sah bahwa seseorang resmi diangkat sebagai anak dalam keluarga, maka dibuatkan surat peras yang akan dilegalisir oleh Camat dan Kepala Desa.

Ter Haar berargumen bahwa dalam perkembangan tata cara pengangkatan anak di hukum adat Bali, diperbolehkan mengangkat anak dari keluarga pihak ibu calon keluarga angkat jika calon ibu dan ayah angkat seorang anak masih memiliki hubungan kekerabatan. Namun, apabila pasangan calon ibu dan ayah angkat bukanlah berasal dari satu keluarga besar yang sama atau tidak memiliki hubungan kekerabatan, maka tidak diperbolehkan mengangkat anak dari garis keluarga ibu, melainkan anak angkat laki-laki dalam keluarga tersebut haruslah berasal dari garis keluarga ayah.

Menurut Awig-awig Oesa Adat Gunaksa dalam Pawos 66 menentukan bahwa

1) Paperasan sane kapatutangring Desa Adat Gunaksa luire ha. Sampun puput mawidhi widhana pamerasanna. Upakarania kasaksinin olih Prajuru Adat Ian Guru Wisesaca. Sampun munggan ring ilikita

a. Perbekel

b. Klian Dadia

c. Klian lbu

d. Klian Banjar

2) Sane kapatutan karajegang sentana luire ha. Warga magama Hindulsaking siosan agama Hindu, sakewanten sanggup magama Hindu na. Kautsahayangwarga sane mawit saking waris kapurusaca. Kautsahayang sane pacang kaperas kantun alitlmangda nellell ngecak patus ring sane manusa lintang 17 tahun sampun mapatusima banjar, ra. Durung marabian saha durung makrama banjar, mangda tan kaucap ngencak patus ka. Meras sentana kengin langkungan ring adiri, lanang wiadin wadon.

Terjemahannya, Pengangkatan anak di Desa Gunaksa mengutamakan anak laki-laki dengan hubungan kekeluargaan yang disahkan kemudian melalui upacara adat yaitu upacara pemerasan dalam pelaksanaannya diselesaikan (dipuput) oleh rohaniawan (Ida Pedanda) dengan kedua belah pihak keluarga sebagai saksi serta Kelian Banjar Adat, Bendesa Adat, Kepala Desa, Kelian Paibon, Pemangku Paibon, Kelian Pemaksan selanjutnya disiarkan pada waktu sangkepan banjar oleh kelian adat serta diikuti dengan pembuatan surat peras sebagai bukti telah dilakukan pengangkutan anak. Kemudian surat-surat tersebut disahkan oleh Kepala Desa dan Camat sehingga pengangkatan anak tersebut menjadi sah.

Syarat untuk diangkat sebagai anak, antara lain

1) Beragama hindu atau di luar agama Hindu, namun bersedia beragama Hindu.

2) Diutamakan dari purusa.

3) Yang diangkat berumur masih kecil atau supaya tidak putus mebanjar dan berumur tidak lebih dari 17 tahun.

4) Belum bersuami istri atau belum mekrama banjar.

5) Meras sentana boleh lebih dari satu, laki rnaupun perempuan. 
Dalam perkembangan yang lebih jauh, hari ini, berdasarkan hukum adat Bali, diperbolehkan mengangkat anak perempuan dengan perkawinan nyeburin dimana anak angkat dijadikan sebagai sentana rajeg-anak perempuan dengan status laki-laki. Keberadaan terobosan semacam ini tidak terlepas dari perubahan masyarakat dalam caranya memandang sebuah isu. Namun, meskipun dengan adanya perkembangan tujuan dasar dari pengangkatan anak di Bali tidaklah berubah menjadikan anak sebagai pewaris dan penerus garis keluarga sepeninggal kedua orang tua angkatnya. Adapun, syarat dan ketentuan yang ketetapannya tercantum dalam hukum adat Bali wajib dipenuhi sebelum mengangkat seorang anak ke dalam sebuah keluarga. Persetujuan semua pihak yang berkepentingan dan pelaksanaan siar dan upacara peras menjadi syarat mutlak yang tidak bisa digantikan. Pada dasarnya pengangkatan anak merupakan upaya dalam menarik anak dari orang lain yang masih mempunyai maupun tidak hubungan darah sama sekali anak dari perbuatan hukum pengangkatan ini disebut anak angkat (Gunawan \& Putranto, 2020). Jika ditinjau dari sistem Hukum Adat, anak angkat diberikan hak yang sama seperti anak kandung namun ada pula yang memberikan hak terhadap anak angkat dengan bagian yang berbeda. Salah satu dasar hukum yang dijadikan pegangan adalah adanya Yurisprudensi dari putusan Mahkamah Agung Republik Indonesia (Karaluhe, 2016). Lebih lanjut, berdasarkan adat Bali apabila anak angkat telah melakukan upacara yadnya dengan meperas, maka kedudukan anak angkat akan sama dengan anak kandung sehingga berhak mewarisi harta benda orang tua angkatnya (Suarini \& Lemes, 2019).

Maka berdasarkan uraian diatas, tujuan penelitian ini dirumuskan untuk mengkaji tata cara adat pengangkatan anak menurut Hukum Adat Bali serta kedudukan anak angkat terkait harta warisan orang tuanya (biologis dan angkat).

\section{METODE PENELITIAN}

Studi dalam penelitian ini dilaksanakan dibawah desain penelitian hukum empiris dimana semua perolehan data didasari pada aspek-aspek empiris (pengamatan dan pengalaman lapangan) dan yuridis-berdasar dokumen hukum yang berlaku di sebuah ternpat (Amiruddin \& Asikin, 2016). Adapun, dalam pelaksanaannya, lewat pengkajian mendalam tentang peraturan dan hukum terkait waris, perkawinan, pengangkatan anak dan kekeluargaan, studi ini memanfaatkan pendekatan gabungan antara pendekatan yuridis dan sosiologis. Dalam penelitian ini Awig-awig Desa Adat Gunaksa, UU No.4/1979, dan UU No.1/1974 merupakan bahan hukum primer. Sedangkan, literarurIiterarur relevan lainnya dimanfaatkan sebagai bahan hukum sekunder untuk membantu proses interpretasi dan analisis data hasil temuan penelitian. Adapun, beberapa sumber literatur yang dipakai, seperti buku, artikel jurnal, pendapat ahli dan cendikiawan, hasil studi, serta hasil karya tulis dan sumber-sumber lain yang terkait dengan topik penelitian baik yang diperoleh secara daring maupun luring. Semua data bahan analisa dalam studi ini dikumpulkan dengan dua teknik pengumpulan data, yaitu teknik wawancara dan dokumentasi. Kemudian, pemilihan sampel dalam studi ini dilakukan dengan Purposive Sampling Technique (teknik sampel bertujuan) yang maksudnya adalah sampel yang dipakai tidak dipilih secara acak melainkan dengan kriteria dan karakter yang disesuaikan dengan topik dan masaJah penelitian dengan maksud agar sampel yang terpilih benar-benar dapat mewakili populasi target dan tercapai generalisasi hasil (Amiruddin \& Asikin, 2016).

\section{HASIL DAN PEMBAHASAN}

\section{Tata Cara Adat Pengangkatan Anak Menurut Hukum Adat Bali}

Pada tiap-tiap daerah dan komunitas adat terdapat peraturan dan tata tertib yang disepakati bersama oleh setiap anggota masyarakat hukum adat setempat, selain itu terdapat pula risiko sanksi bagi pelanggaran yang terjadi. Sanksi yang dibebankan kepada pelanggar bermacam-rnacam bentuknya dan dilaksanakan oleh penegak peraturan yang berasal dari kelompok masyarakat yang sama. Lain halnya dengan pelanggaran peraturan perundang-undangan tertulis yang ditetapkan oleh pemerintah, maka sanksi pelanggaran yang dibebankan kepada pelanggar akan melalui putusan aparat pemerintahan. Keberadaan peraturan, baik yang tertulis ataupun tidak menjadikan kehibupan dalam bermasyarakat lebih teratur dan tertib. Selain iru, peraturan menjadi koridor individu dalam bertindak agar selalu memperhatikan setiap norma dan nilai yang berlaku dan tidak bertindak secara semaunya sendiri karena sesungguhnya dalam kehidupan bermasyarakat ada hak-hak orang lain yang harus kita indahkan dan horrnati. Dalam kasus pengangkatan anak di Lokasi penelitian, terdapat syarat dan ketentuan umum yang telah ditetapkan dalam Hukum data Bali, yakni 1) proses pengangkatan anak hams melalui persetujuan pihak keluarga anak yang diangkat ataupun keluarga calon orang tua 
angkat, 2) Kesamaan iman antara kedua belah pihak keluarga, sama-sama penganut agama Hindu 3) pengutamaan anak laki-laki sebagai calon anak angkat, 4) calon anak angkat berstatus belum menikah dan masih muda.

Dalam Awig-awig Desa Adat Gunaksa syarat-syarat pengangkatan anak diatur dalam Pawos 66 yang menentukan bahwa Sane kapatutan karajegang sentana luire. Warga magama Hindu/saking siosan agama Hindu, sakewanten sanggup magarna Hindu (Beragama hindu atau di luar agama Hindu, namun bersedia beragama Hindu), 2) Kautsahayang warga sane mawit saking waris kapurusa (Diutamakan dari purusa), 3) Kautsahayang sane pacang kaperas kantun alit/mangda nenten ngecak patus ring sane manusa lintang 17 tahun sampun mapatus/mabanjar (Yang diangkat berumur masih kecil atau supaya tidak putus mebanjar dan berumur tidak lebih dari 17 tahun), 4) Durung rnarabian saha durung rnakrarna banjar, mangda tan kaucap ngencak patus (Belum bersuami istri atau belum mekrama banjar), 5) Meras sentana kengin langkungan ring adiri, lanang wiadin wadon (Meras sentana boleh lebih dari satu, laki maupun perempuan).

Keberadaan peraturan dan ketentuandiatas merupakan sebuah usaha unruk mencegah risiko terjadinya perselisihan antara kedua belah pihak yang berkepentingan dalam proses pengangkatan anak. Berdasar pada pasal-pasal diatas, maka diketahui bahwa musyawarah penentuan calon anak angkat sebaiknya dilakukan terlebih dahulu di dalam keluarga calon orang tua angkat sebelum kemudian menyampaikan maksud kepada pihak keluarga calon anak angkat. Barulah setelah semua hal tersebut dijalankan-mendapat persetujuan dari semua pihak berkepentingan-maka upacara pemerasan/Widhi Widana dapat dilancarkan.

Bendesa Adat Desa Gunakasa (Ir. I Nengah Ariyanta) menyatakan pada wawancara pada 29 Januari, 2021 bahwa sebelum pelaksanaan prosesi pengangkatan anak di desanya, ada beberapa prasyarat yang harus dipenuhi, antara lain I) calon anak anak angkat diutamakan yang berasal dari pihak keluarga calon ayah angkat (pursua), jika tidak ada/tidak ada yang mau barulah mengambil anak dari pihak keluarga calon ibu angkat (predana), 2) pengangkatan calon anak dari luar pihak keluarga purusa/predana hanya dilakukan jika tidak mendapatkan kandidat dari dalam pihak keluarga. Kemudian, karena wanita tidak memiliki hak sebagai ahli waris, maka tidak diperkenankan pengangkatan anak bagi individu dengan status janda di Bali tanpa persetujuan terlebih dahulu dari pihak mendiang suarninya. Adapun persyaratan lain adalah calon anak angkat harus berasal dari keturunan terdekat dari pihak keluarga mendiang suami dari janda tersebut. (Putusan Pengadilan Negeri Denpasar di Klungkung tanggal 3 Oktober 1966 Nomor 84/PDT/ 1966).

Dalam kesempatan lain, Kelian Adat desa Gunaksa (I Wayan Sudiarta, SH) menyatakan dalam wawancara pad a 29 Januari, 2021 bahwa di pandang perlu adanya prasyarat lain yang harus dipenuhi dalam pemerasan sentana, yakni kedua pihak, baik calon anak angkat ataupun orang tua angkat harus beragama Hindu, dan harus ada hubungan kekerabatan dengan predana/purusa. Calon anak dari keinginan personal purusa dan predana barn diperbolehkan jika tidak ada kandidat potensial dari kalangan keluarga besar.

Sebab itu, penting bagi masyarakat hukum adat Bali, khususnya di desa Gunaksa untuk memperhatikan serta melaksanakan segala syarat dan ketentuan yang telah disepakati agar dikemudian hari tidak ada perselisihan. Sesungguhnya segala tindak pelanggaran akan kerentuan tersebut memungkinkan timbulnya masalah dan keharmonisan di kemudian hari serta ketidakseimbangan relasi antara Desa dan Banjamya. Jika diperhatikan lebih detail, dapat dilihat bahwa persetujuan serta kesepakatan kedua pihak berkepentingan menjadi syarat yang muncul pada urutan pertama. Maka dari itu hal ini haruslah menjadi perhatian utama sebelum pelaksanaan prosesi upacara pemerasan dilakukan. Hal ini mengandung arti bahwa kesepakatan akan menjadi syarat mutlak yang menjadikan kedudukan anak angkat dalam Hukum Adat Bali adalah sama sebagaimana anak kandung-sebagai pewaris dan penerus kedua orangtua angkatnya (Satrio, 2000).

Data dalam penelitian ini menyasar kepada lima (5) orang anak angkat laki-Iaki yang ada di Desa Gunaksa, Bali. Dengan ditemukannya fakta ini, dapat diketahui bahwa praktik sistem kekeluargaan patrilineal masih ada dan dianut dalam kehidupan masyarakat Hukum Adat Desa Gunaksa. Prosedur PengangkatanAnak Di Desa Gunaksa I Wayan Sudiarna, dalam wawancara sebagai Penyarikan Desa Gunaksa yang diJakukan pada 29 Januari, 2021 menyatakan rupa dan jenis pewarisan daJam pemerasan dikategorikan menjadi 1) Benda pusaka dengan nilai magis religius dimana fungsinya mengekalkan ikatan cinta kasih antara orangtua angkat dan anak angkatnya. Adapun, bentuk dari harta benda semacam ini mulai dari perhiasan kebesaran dan pakaian (cincin, 
permata, geluangan, dan lainnya), sarana prasarana ibadah (sangku, bajra, alat pemujaan, dan/atau lainnya) hingga senjata pusaka (tombak, keris, dan lainnya). 2) warisan yang bemilai ekonomis, seperti bidang tanah, tabungan, surat berharga, uang dan Jainnya dimana kesemuanya difungsikan sebagai penjamin kehidupan anak angkat sepeninggal orang tua angkatnya.

Korn menyatakan bahwa, secara umum, pembuatan surat permohonan yang ditembuskan ke Pengadilan negeri lewat kepada Bupati setempat yang sebelumnya melalui camat merupakan syarat berlaku bagi pihak yang ingin mengangkat anak dalam keluarganya. Namun, dalam praktiknya ada beberapa kasus dimana pengangkatan anak tidak disertai dengan surat permohonan. Adapun, Permohonan tersebut dibuat secara langsung bersamaan dengan prosesi upacara adat pemerasan. Pasal 11 ayat 4 paswara yang disahkan pada 13 Oktober, 1900 telah mengatur tiap transaksi pengangkatan anak sentana harus dibuatkan surat di kantor Kepala kabupaten (controlir) .

Dalam wawancara lain bersama Ir. I Nengah Arianta sebagai Bendesa Gunaksa pada 29 Januari, 2021 didapatkan informasi bawa hingga kini belum terdapat akta pengangkatan anak melalui notaris yang dibuat di kalangan masyarakat Hukum Adat Gunaksa. Upacara adat dan segala prosesi terkait adat istiadat masih dipegang teguh sebagai syarat mutlak adanya pengangkatan anak di desa Gunaksa. Mengenai prosedur pengangkatan anak di Desa Gunaksa Tiga bulan sebelum dilakukan pengangkatan anak maka ca Ion orang tua angkat dan orang tua kandung anak tersebut melapor kepada Prajuru Banjar Adat dan Prajuru Banjar Dinas. Setelah saru minggu menerima laporan maka akan diadakan pemanggilan untuk memastikan rencana pengangkatan anak yang sudah sama-sama setuju. Apabila calon orang tua angkat dan orang tua kandung sudah sepakat maka prajuru Kelian Banjar Adat dan Prajuru Banjar Dinas akan memanggil para ahli waris kalau ada untuk memastikan setuju atau tidaknya rencana pengangkatan anak tersebut (pemerasan). Apabila proses tersebut semuanya sudah pada sepakat sesuai dengan awig-awig Desa Gunaksa, maka selanjutnya Kelian Banjar Adat Dan Kelian Banjar Dinas menyampaikan maksudnya sesuai dengan rencana kepada Bendesa Adat dan Kepala Desa.

Pada Waktu pengangkatan anak (peperasan) wajib dilakukan upacara dan disaksikan oleh penjuru atau kelian ban jar adat, bendesa adat, Kepala Desa, Kelian Paibon, Pernangku Paibon, Kelian Pernaksan dan dibuktikan dengan penandatanganan administrasi pengangkatan anak (peperasan) secara adat. Terdapat salah satu proses yang dinamakan dengan pemegat dimana didalamnya dilakukan pembakaran benangg tridatu hingga putus sebagai simbolisme pemutusan hubungan antara anak angkat dengan orangtuanya. Selain itu, ada pula prosesi penyerahan harta pemesaran yang diberikan kepada anak angkat serta pembayaran adat dengan satu set pakaian perempuan dan uang senilai seribu kepeng yang diberikan kepada ibu biologis anak angkat sebagai tanda serah terima dan pemutusan hubungan kekeluargaan. Terkait status kepemilikan harta pemerasan yang telah diserahkan adalah menjadi hak anak angkat selamanya dan bersifat mutla.k terhitung seja.k penutupan upacara pemerasan. Demikianlah, setelah penyiaran upacara pemerasan daJam sangkepan oleh kelian adat maka anak angkat dinyatakan sah sebagai bagian dari keluarga orangtua angkatnya dan berkedudukan selayaknya anak kandung di mata masyarakat.

Didapatkan informasi terkait harta pemerasan yang diserahkan kepada ana.k angkat dari wawancara bersama I wayan Sadiarna sebagai Carik Desa Gunaksa pada 29 Januari, 2021 dimana terdapat dua kategori harta. Harta dengan nilai ekonomis, seperti bidang tanah, tabungan, surat berharga, uang, emas, dan lainnya. Maksud pemberian harta yang demikian adalah sebagai penjamin kelangsungan hidup anak angkat sepeninggal orang tua angkatnya. Harta dengan nilai magis religius dengan fungsi sebagai simbolisme pengikat hubungan cinta kasih antara orangtua angkat dengan anak angkatnya, seperti perhiasan kebesaran (cincin dengan permata bemilai, geluangan, dan lainnya), prasarana ibadah (sangku, bajra, alat pemujaan dan sebagainya), senjata pusaka (tombak, keris dan lainnya) serta pakaian.

\section{Kedudukan Anak Angkat terkait Harta Warisan Orang Tuanya (Biologis Dan Angkat)}

Dalam Hukum Adat Bali, pengangkatan anak dilakukan dalam ketentuan yang berlaku pada sistem kekeluargaan patrilineal dan anak angkat berkedudukan selayaknya ana.k kandung dalam keluarga angkatnya. Adapun, Soeripto berpendapat bahwa terdapat kepemilikan harta benda bemilai magis religius-berhubungan dengan prosesi peribadatan dalam agama Hindu. Pada tiap-tiap keluarga Hindu di Bali dan juga keberadaan serta kepemilikan harta diluar nilai-nilai keagamaan, diantaranya harta druwa gabro, harta tetatadan, harta jiwadana dan harta akaskaya (Meliala, 2016). 
Dalam kehidupan masyarakat Bali, kedudukan sebagai pewaris sah harta yang meliputi dan tidak terkecuali harta Druwe gabro, harta tetatadan, harta jiwa, dan harta akas kaya dari orang tua angkat kepada anak angkat merupakan kesepakatan di kalangan sarjana hukum adat waris (Hadikusuma, 2015). Namun, dalam praktiknya hingga hari ini, untuk pencegahan terjadinya sengketa dan perselisihan di kemudian hari, maka anak angkat yang diserahkan padanya baik harta bernilai magis religious dan harta guna kaya merupakan mereka yang berasal dari kalangan keluarga dan sanak saudara orang tua angkat, sedangkan bagi anak angkat yang berasal dari luar keluarga besar orang tua angkat, hak warisnya terbatas hanya pada harta guna kaya dimana harta benda pusaka yang bernilai religious dikemnalikan kepada orang tua angkat dan keluarganya.

Dalam bukunya Hukum Waris Hindu yang kemudian diadaptasi dalam Hukum Adat Lombok dan Bali, I Gede Pudja berpandangan bahwa hilangnya agama leluhur pada anak angkat merupakan kedurhakaan pada leluhur dan mestinya menjadi sebab lain penghapusan kedudukannya sebagai pewaris karena hal ini berujung pada hilangnya peran mereka sebagai putra leluhur penerus orang tua angkat dalam pelaksanan kewajiban beragarna dan peran dalam kehidupan adatnya (Pudja, 1977). Seperti yang telah dibahas sebelumnya, dalam Hukum Adat Bali, anak yang telah menjalani proses upacara pemerasan terikat hubungan kekeluargaannya dengan orangtua angkat disertai dengan pemutusan hubungan dengan keluarga kandungnya.

Pemutusan hubungan ini berakibat pada putusnya kewajiban anak terhadap leluhur dan orang tua kandungnya. Selain itu, pemutusan ini berarti merubah kedudukan anak angkat sebagai penerus dan pewaris sah dari orangtua angkat beserta dengan kewajiban dan hak yang melekat pada mereka.

Dari poin tersebut, nampak sangat jelas bahwa ketentuan pemutusan hubungan anak angkat dengan orangtua kandungnya menghapus segala kewajiban dan hak yang sebelurnnya di predikatkan padanya dalam keluarga orangtua kandungnya. Soepomo, berhubungan dengan hal ini, menyatakan Seorang Putra karena diangkat oleh keluarga lain, keluar dari hubungan keluarga ayahnya, sehingga ia kehilangan segala hak untuk mewarisi pusaka ayahnya (Soepomo, 2000).

Berdasar pada data hasil studi di Desa Adat Desa Gunaksa, hal yang sama juga berlaku dimana hubungan seorang sentana (anak angkat) dengan orangtua kandungnya terhapus ketika mereka telah menjalani prosesi upacara pemerasan. Namun, dalam perkembangannya hari ini, ada pula banyak kasus dimana terdapat anak yang diangkat sebagai sentana rajeg-anak perempuan kandung yang diberikan status sebagai anak laki-laki-dengan alasan dimana dalam keluarga persua/predana tidak terdapat keturunan laki-laki.

\section{SIMPULAN DAN SARAN}

\section{Simpulan}

Menurut Hukum Adat Bali, dalam pranata pemerasan diutamakan bagi anak laki-laki yang ada hubungan kekeluargaan kemudian dilakukan upacara adat yaitu upacara pemerasan dalam pelaksanaannya diselesaikan (dipuput) oleh rohaniawan (Ida Pedanda) dengan kedua belah pihak keluarga beserta Kelian Banjar Adat, Bendesa Adat, Kepala Desa, Kelian Paibon, Pemangku Paibon, Kelian Pemaksan berlaku sebagai saksi dan kemudian disiarkan pada waktu sangkepan banjar oleh kelian adat beserta dengan pembuatan surat peras sebagai bukti telah dilakukan pengangkatan anak pada saat yang bersamaan. Kemudian surat-surat tersebut disahkan oleh Kepala Desa dan Camat sehingga pengangkatan anak tersebut menjadi sah. Fungsi dan kedudukan anak angkat setelah prosesi pemerasan adalah setara dengan anak kandung-sebagai pewaris dan penerus kewajiban dan hak yang melekat pada orangtua angkat. Selain itu terdapat detail ketentuan dimana pewarisan harta bagi anak yang berasal dari kalangan keluarga besar orangtua angkatnya meliputi harta pusaka dan harta guna kaya, sedangkan bagi anak angkat yang berasal dari luar keluarga besar orangrua angkat pewarisan harta kepadanya terbatas hanya pada harta guna kaya saja dan kepemilikan harta pusaka dikembalikan kepada orangtua angkat dan keluarganya. Kemudian, hak dan kewajiban anak angkat terhadap orangtua kandungnya, pada saat yang bersamaan menjadi terhapuskan.

\section{Saran}

Kepada Orang tua yang ingin mengangkat anak, sebaiknya tidak terlalu membatasi pilihan hanya pada lingukngan keluarga purusa/predana saja melainkan yang lebih penting adalah memilih anak yang mampu secara penuh bertanggungjawab dalam melaksanakan kewajiban dan hak yang melekat padanya sebagai bagian keluarga orangrua angkatnya. Bagi para orangtua angkat, khususnya di Desa 
Adat Gunaksa, hendaklah membuat surat peras meskipun telah ada pelaksanaan upacara pemerasan. Dokumen ini sangat penting sebagai bukti tertulis dan penguatan kedudukan anak angkat di mata negara dengan adanya putusan resmi dari Pengadilan Negeri serta terdapat kepastian dan perlindungan hukum atasnya.

\section{DAFTAR PUSTAKA}

Amiruddin, \& Asikin, Z. (2016). Pengantar Metode Penelitian Hukum. PT. Raja Grafindo Persada, Jakarta.

Gunawan, \& Putranto, M. R. D. (2020). Kedudukan Anak Angkat Terhadap Harta Warisan Berdasarkan Hukum Waris di Indonesia. Media Juris, 3(2), 161-180.

Hadikusuma, H. H. (2015). Hukum Waris Adat. PT. Citra Aditya Bakti, Bandung.

Karaluhe, S. S. (2016). Kedudukan Anak Angkat dalam Mendapatkan Harta Warisan ditinjau dari Hukum Waris. Jurnal Lex Privatum, 4(1), 166-174.

Meliala, D. S. (2016). Pengangkatan anak (adopsi) berdasarkan adat kebiasaan setempat dan peraturan perundangan di Indonesia. Nuansa Aulia, Bandung.

Pudja, G. (1977). Pengantar Tentang Perkawinan Menurut Hukum Hindu. Mayasari, Jakarta.

Satrio, J. (2000). Hukum Keluarga tentang Kedudukan Anak dalam Undang-undang. Citra Adirya Bakti, Bandung.

Soepomo, R. (2000). Bab-bab Tentang Hukum Adat. Pradnya Paramita, Jakarta.

Suarini, N. L. P. D., \& Lemes, I. N. (2019). Kedudukan Anak Angkat dalam Hal Waris ditinjau dari Hukum Adat Bali di Desa Depeha Kecamatan Kubutambahan Kabupaten Buleleng. Kertha Widya, 7(2), 92-106.

Zaini, M. (2002). Adopsi Suatu Tinjauan Dari Tiga Sistem Hukum. Sinar Grafika, Jakarta. 